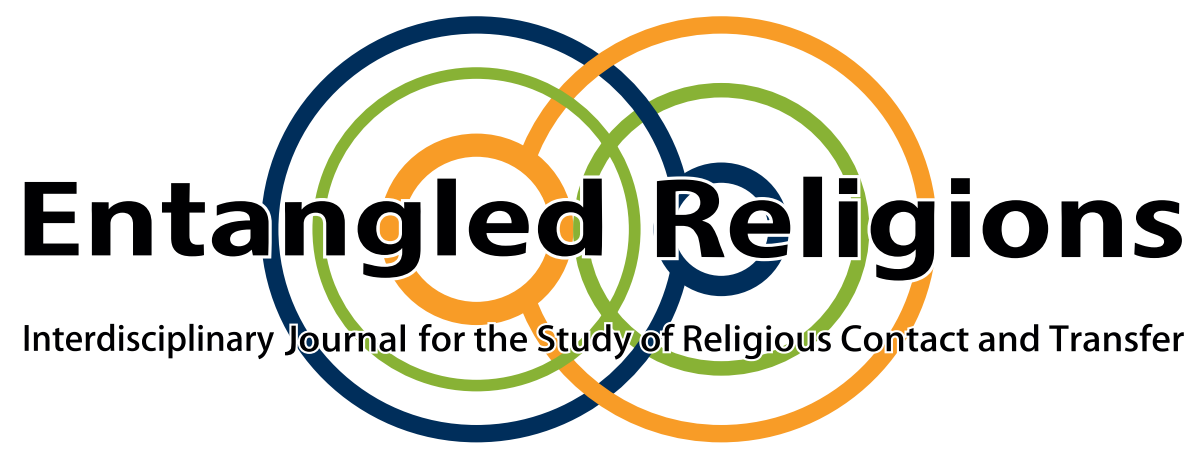

\title{
Editorial
}

\section{A Look Back Upon 2014}

VIVIAN STROTMANN

Ruhr-Universität Bochum, Käte-Hamburger Kolleg "Dynamics in

the History of Religions between Asia and Europe", Germany

(C) 2014 Ruhr-Universität Bochum ISSN 2363-6696

RUHR

UNIVERSITÄT

BOCHUM

RUB
Entangled Religions 1 (2014)

http://dx.doi.org./10.13154/er.v1.2014.a-d

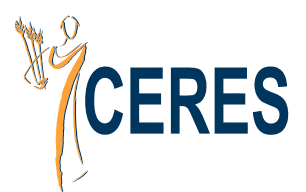

SPONSORED BY THE

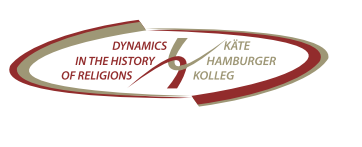

of Education and Research 


\title{
Editorial
}

\author{
A Look Back Upon 2014
}

VIVIAN STROTMANN

Ruhr-Universität Bochum

\section{The year is coming to an end...}

And we look back upon exciting times!

In June 2014, works on the project of Entangled Religions picked up pace behind the scenes. With the support of partners, such as the central library of Ruhr-University Bochum and funding from the German Federal Ministry of Education and Research, the new website of our journal went online on 4 November, 2014. In these two months online, we have continually improved our website to offer you the best service possible. We have published 4 articles with a total of 158 pages.

In additon to the present editorial, Entangled Religions Vol. 1 (2014) consists of the following contributions:

1. Vivian Strotmann: “Editorial: Welcome to Entangled Religions!” , pp. 1-13.

2. Jessie Pons: "The Figure with a Bow in Gandhāran Great Departure Scenes. Some New Readings", pp. 15-94. 
3. Stuart Ray Sarbacker: "Reclaiming the Spirit through the Body: The Nascent Spirituality of Modern Postural Yoga", pp. 95-114.

4. Gerdien Jonker: “The Dynamics of Adaptive Globalisation: Muslim Missionaries in Weimar Berlin", pp. 115-158.

These contributions were thematically diverse and treated subjects such as:

- Ahmadiyya mission

- B. K. S. lyengar

- Buddhist iconography

- Buddhist philosophy

- cosmopolitanism

- Gandhāra

- hațhayoga

- Hindu philosophy

- interdisciplinary research

- inter-war continental Europe

- K. Pattabhi Jois

- Kushan era

- Lebensreform

- Muslim mainstream mission

- multiple identities

- postural yoga

- religious transfer

- Vaiśravaña-Kubera 


\section{...and a new one is about to begin!}

In 2015, Entangled Religions - Interdisciplinary Journal for the Study of Religious Contact and Transfer will continue to publish.

For your convenience, we will add new features. To offer you interesting reading, we will establish new sections in our journal.

We look forward to sharing the year 2015 with you! 